\title{
KEPADATAN YANG BERBEDA TERHADAP PERTUMBUHAN DAN SINTASAN BENIH IKAN NILA GIFT (Oreochromis niloticus) DALAM WADAH TERKONTROL
}

\author{
Yanti Mutalib $^{1 *)}$, Dahlan') \\ ${ }^{1,2)}$ Program Studi Budidaya Perairan, Fakultas Perikanan, Universitas \\ Muhammadiyah Luwuk \\ "E-mail: yantimutalib@ymail.com
}

\begin{abstract}
ABSTRAK
Penelitian ini bertujuan untuk mengetahui pengaruh tingkat kepadatan yang berbeda terhadap pertumbuhan dan sintasan benih ikan nila gift Oreochromis niloticus. Hasil penelitian ini diharapkan dapat menjadi salah satu bahan informasi terhadap pembudidayaan ikan nila $O$. niloticus dengan menerapkan padat penebaran yang optimal untuk menunjang pertumbuhan dan sintasan ikan nila gift O. niloticus. Penelitian ini dilaksanakan pada bulan Juli sampai Agustus 2017 bertempat di Laboratorium Fakultas Perikanan Universitas Muhammadiyah Luwuk. Pada penelitian ini menggunakan Rancangan Acak Lengkap (RAL) yang terdiri dari lima perlakuan dan tiga ulangan perlakuan, sehingga terdapat 15 unit percobaan. Untuk mengetahui apakah kepadatan memberikan pengaruh terhadap pertumbuhan dan sintasan, maka dilakukan uji statistik menggunakan analisis ragam, dengan tingkat kepercayaan $95 \%$ bila terjadi perbedaan antara perlakuan, maka dilanjutkan dengan uji BNT atau LSD. Berdasarkan data rata-rata laju pertumbuhan spesifik harian benih ikan nila menunjukkan bahwa perlakuan A (5 ekor/wadah), B (10 ekor/wadah), C (15 ekor/wadah), D (20 ekor/wadah) dan E (25 ekor/wadah). Persentase rata-rata sintasan tertinggi terdapat pada perlakuan B (60 \%), A (53.33 \%), D (15\%), E (12.99\%) dan perlakuan C (11.11\%). Hasil pengukuran kualitas air selama penelitian masih dalam kisaran yang layak bagi pertumbuhan dan kelangsungan hidup ikan nila, dimana suhu $25^{\circ} \mathrm{C}-27^{\circ} \mathrm{C}$, pH 7.0 - 7.4 dan DO 5.7 ppm.
\end{abstract}

Kata Kunci: ikan nila, kepadatan, pertumbuhan, sintasan.

\section{PENDAHULUAN}

Ikan air tawar merupakan komoditas perikanan air tawar yang saat ini banyak menghasilkan devisa. Seiring dengan meningkatnya jumlah penduduk dunia dan kebutuhan akan bahan pangan dan gizi yang lebih baik, permintaan ikan terus meningkat dari tahun ke tahun. Asia, selain sebagai produsen ikan terbesar, diperkirakan juga menjadi konsumen terbesar dari hasil perikanan dunia.

Usaha budi daya ikan semakin hari semakin bertambah intensif, sejalan dengan kemajuan zaman dan teknologi.Masyarakat semakin cenderung untuk memanfaatkan lahan yang tersedia semaksimal mungkin, sehingga produksi per satuan luas semakin meningkat.Keberhasilan suatu usaha budi daya sangat erat kaitannya dengan kondisi lingkungan yang optimum untuk kelangsungan hidup dan pertumbuhan ikan yang dipelihara (Mulyadi et al., 2014). 
Dalam kegiatan budidaya salah satu aspek yang perlu diperhatikan adalah tingkat kepadatan penebaran. Menurut Hatimah (1991). Pada padat penebaran yang tinggi akan menghasilkan produksi yang tinggi tetapi berat individu kecil, tetapi sebaliknya apabila padat penebaran rendah akan menghasilkan produksi yang rendah dengan berat individu besar.

Oleh karena itu, perlu dilakukan penelitian untuk menjelaskan pengaruh padat penebaran terhadap pertumbuhan dan kelangsungan hidup ikan nila gift dan menjelaskan padat penebaran yang optimal terhadap petumbuhan dan kelangsungan hidup ikan nila gift ( $O$. nilotius).

\section{BAHAN DAN METODE \\ Waktu dan Tempat}

Penelitian ini dilaksanakan pada bulan Agustus sampai September 2017 bertempat di Laboratorium Fakultas Perikanan Universitas Muhammadiyah Luwuk.

\section{Alat dan Bahan}

Alat dan bahan yang telah digunakan dalam pelaksanaan penelitian ini dapat dilihat pada Tabel 1:

Tabel 1. Alat yang digunakan

\begin{tabular}{ll}
\hline Alat & Fungsi \\
\hline Timbangan & Untuk menimbang hewan uji \\
Serok & Untuk mengambil hewan uji \\
Blower & Untuk alat Penyuplai Oksigen terlarut \\
Buku dan pulpen & Untuk alat tulis menulis \\
Selang kecil & Untuk menyipon kotoran yang \\
& mengendap pada dasar wadah. \\
Kertas tissue & Untuk pembersihan alat-alat yang di \\
& gunakan. \\
Thermometer, DO meter, pH meter & Untuk mengukur parameter kualitas air \\
\hline
\end{tabular}

Tabel 2. Bahan yang digunakan

\begin{tabular}{ll}
\hline Bahan & Fungsi \\
\hline Benih ikan nila gift & Sebagai hewan uji \\
Pakan & Sebagai pakan ikan \\
\hline
\end{tabular}

\section{Wadah Percobaan}

Wadah percobaan penelitan yang digunakan berupa ember yang berbentuk bulat, berukuran delapan liter air, memiliki tinggi $23 \mathrm{~cm}$ dan diameter alas $20 \mathrm{~cm}$ sebanyak 15 buah. 


\section{Hewan Uji}

Hewan uji yang digunakan dalam penelitian ini adalah benih Ikan nila gift $(O$. niloticus) dengan bobot rata-rata 2.1 - 2.75 gram/ekor dan berukuran panjang 3-5 $\mathrm{cm}$ yang diperoleh dari Balai Benih Ikan (BBI) Hunduhon Kecamatan Luwuk Timur.

\section{Pakan Uji}

Pakan yang digunakan selama penelitian adalah pakan komersil F999 berbentuk pellet.

\section{Rancangan Penelitian}

Pada penelitian ini menggunakan Rancangan Acak Lengkap (RAL) yang terdiri dari lima perlakuan dan tiga ulangan sehingga terdapat 15 unit percobaan. Adapun perlakuan dan lay out yang digunakan:

Perlakuan A = kepadatan 5 ekor / wadah.

Perlakuan B = kepadatan 10 ekor / wadah

Perlakuan $\mathrm{C}=$ kepadatan 15 ekor / wadah

Perlakuan D = kepadatan 20 ekor / wadah

Perlakuan $\mathrm{E}=$ kepadatan 25 ekor / wadah

\section{Analisis Data}

Untuk mengetahui apakah kepadatan memberikan pengaruh terhadap pertumbuhan dan sintasan, maka dilakukan uji statistik menggunakan Analisis Ragam (ANOVA). Dengan tingkat kepercayaan 95\% bila terjadi perbedaan antara perlakuan, maka dilanjutkan dengan uji LSD (Gaspersz, 1991).

\section{HASIL DAN PEMBAHASAN}

\section{Laju Pertumbuhan Harian}

Berdasarkan data hasil penelitian kepadatan yang berbeda terhadap laju pertumbuhan benih ikan nila gift selama penelitian menunjukkan bahwa laju pertumbuhan spesifik diperoleh data rata-rata laju pertumbuhan benih ikan nila gift disajikan pada Tabel 3 .

Tabel 3. Rata-rata laju pertumbuhan harian benih ikan nila setiap perlakuan selama penelitian.

\begin{tabular}{cc}
\hline Perlakuan & $\begin{array}{c}\text { Rata-rata laju pertumbuhan } \\
\text { harian } \\
(\overline{\mathrm{X}} \pm \text { STDEV })\end{array}$ \\
\hline A (kepadatan 5 ekor/wadah) & $3.780 .74^{\mathrm{a}}$ \\
B (kepadatan 10 ekor/wadah) & $1.500 .49^{\mathrm{a}}$ \\
C (kepadatan 15 ekor/wadah) & $3.711 .36^{\mathrm{a}}$ \\
D (kepadatan 20 ekor/wadah) & $1.950 .20^{\mathrm{a}}$ \\
E (kepadatan 25 ekor/wadah) & $3.25 \pm 1.18^{\mathrm{a}}$ \\
\hline
\end{tabular}

Keterangan : Huruf superscrip yang sama pada baris yang berbeda Tidak berbeda nyata pada taraf (Fhit $<\alpha 0.05)$ 
Berdasarkan hasil sidik ragam pada (lampiran 3) dan rata-rata laju Pertumbuhan spesifik harian benih ikan nila (Tabel 4) menunjukkan bahwa perlakuan A, B, C, D dan E. Tidak berbeda nyata $(\alpha<5 \%)$, hal ini karena nilai F hitung (1.054) lebih kecil dari F tabel (3.48) pada taraf $5 \%$ sehingga diantara lima perlakuan A, B, C, D dan E tidak terdapat pertumbuhan yang signifikan. Pada (Gambar 3) menunjukan bahwa setiap pertambahan kepadatan akan memberikan penurunan terhadap pertumbahan bobot ikan, sehingga semakin tinggi padat penebaran akan menghasilkan pertumbuhan bobot semakin rendah.

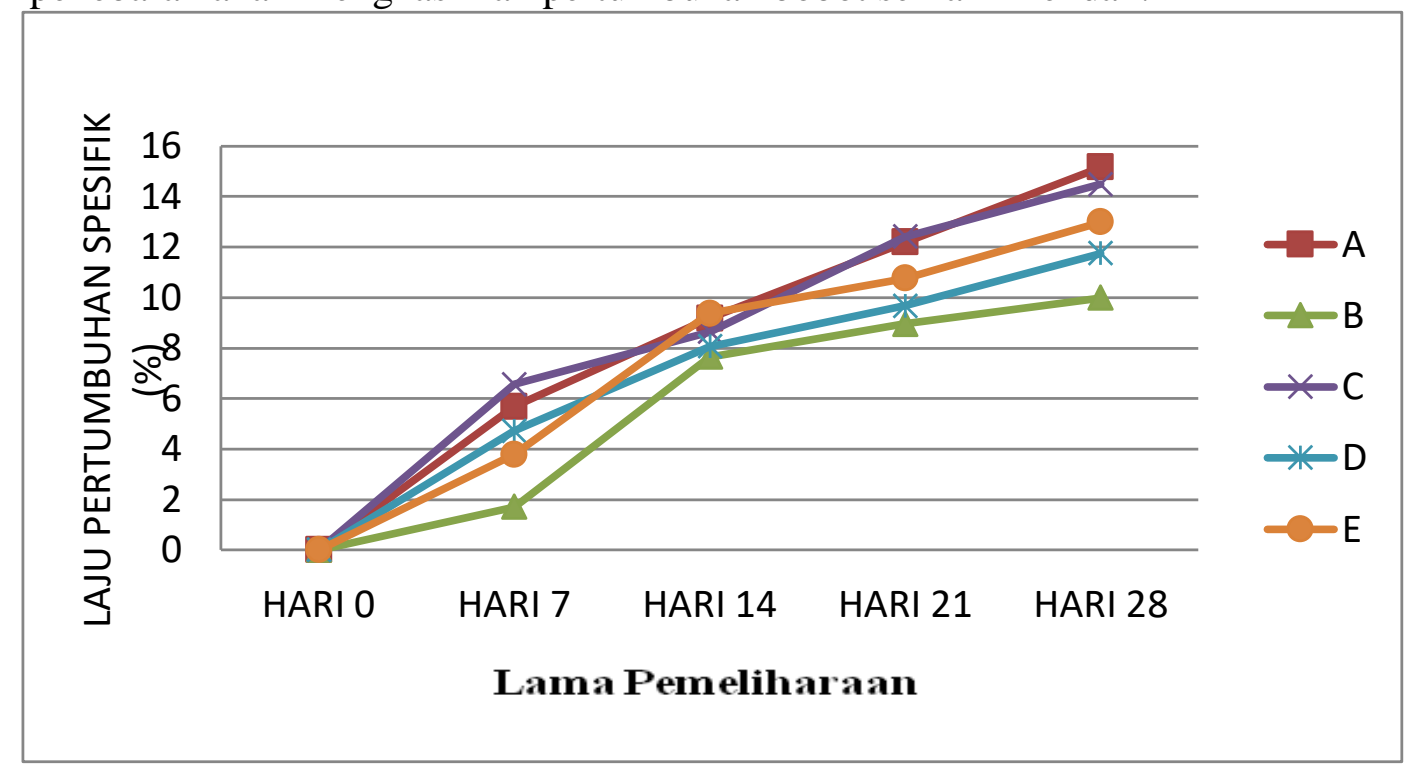

Gambar 1. Laju pertumbuhan spesifik benih ikan nila selama penelitian

Hal ini disebabkan benih ikan pada padat penebaran 5 ekor tidak mengalami persaingan yang tinggi dalam hal persaingan pakan, ruang gerak, dan oksigen. Sebagaimana dinyatakan Kadarini et al. (2010) bahwa kompetisi ruang gerak dapat mempengaruhi pertumbuhan ikan, dikarenakan dengan padat tebar berbeda dalam wadah yang luasannya sama pada masing-masing perlakuan, dimungkinkan terdapat persaingan dalam hal kesempatan mendapatkan pakan. Keadaan tersebut menyebabkan kondisi ikan lemah sehingga pemanfaatan pakan tidak optimal, hal ini mengakibatkan pertumbuhan ikan terganggu dan akhirnya menjadi lambat.

\section{Sintasan}

Hasil penelitian data perhitungan sintasan benih ikan nila O. niloticus didapatkan data rata-rata sintasan benih ikan nila yang terdapat pada Tabel 4 berikut: 
Tabel 4. Rata-rata sintasan benih ikan nila selama penelitian

\begin{tabular}{ll}
\hline Perlakuan & $\begin{array}{l}\text { Rata-rata Sintasan } \\
(\overline{\mathrm{X}} \pm \text { STDEV })\end{array}$ \\
\hline A (kepadatan 5 ekor/wadah) & $53.33 \pm 30.55^{\mathrm{a}}$ \\
B (kepadatan 10 ekor/wadah) & $60 \pm 10^{\mathrm{a}}$ \\
C (kepadatan 15 ekor/wadah) & $11.11 \pm 3.85^{\mathrm{b}}$ \\
D (kepadatan 20 ekor/wadah) & $10 \pm 5^{\mathrm{b}}$ \\
E (kepadatan 25 ekor/wadah) & $8 \pm 4^{\mathrm{b}}$ \\
\hline
\end{tabular}

Keterangan: Huruf superscrip yang sama pada baris menunjukkan perlakuan berbeda nyata (Fhit $>0.05)$

Berdasarkan tabel (4) dan sidik ragam lampiran (4) menunjukkan bahwa, kepadatan yang berbeda memberikan pengaruh yang sangat nyata terhadap sintasan benih ikan nila. Dari hasil uji BNT Lampiran (5) menunjukkan bahwa perlakuan A (5 ekor/wadah) berbeda sangat nyata terhadap perlakuan C (15 ekor/ wadah), D (20 ekor/wadah) dan E (25 ekor/wadah), kemudian perlakuan B (10 ekor/wadah) berbeda sangat nyata terhadap perlakuan C (15 ekor/wadah), D (20 ekor/wadah) dan E (25 ekor/wadah), Sedangkan perlakuan C (15 ekor/wadah) tidak berbeda nyata terhadap perlakuan D (20 ekor/wadah) dan E (25 ekor/wadah). Sedangkan perlakuan D (20 ekor/wadah) tidak berbeda nyata terhadap perlakuan E (25 ekor/wadah), kemudian perlakuan A (5 ekor/wadah) tidak berbeda nyata dengan perlakuan B (10 ekor/wadah).

Persentase rata-rata sintasan tertinggi terdapat pada perlakuan B (10 ekor) $60 \%$, A (5 ekor) $53.33 \%$, C (15 ekor) $11.11 \%$, D (20 ekor) $10 \%$ dan perlakuan E (25 ekor) $8 \%$. Tingginya sintasan pada perlakuan B diduga karena ikan lebih merespon pakan dibandingkan perlakuan lainnya, disamping itu juga adanya faktorfaktor lain yang mempengaruhi sintasan ikan seperti adanya kompetisi diantara ikan.

Menurut Khairuman dan Amri, (2008) menyatakan bahwa sintasan ikan uji dipengaruhi oleh beberapa faktor diantaranya cara pemeliharaan, kandungan nutrisi pakan dan kualitas air. Hasil pengamatan, tingkat kelangsungan hidup (survival rate) benih ikan nila selama penelitian bahwa ikan yang mati pada saat penelitian disebabkan karena pada awal penelitian ikan tidak diaklimatisasi terlebih dahulu.

Menurut Kuncoro (2004), indikator keberhasilan kegiatan pengadaptasian adalah terlihat pada tingkah laku ikan yang positif merespon pakan. Kematian ikan yang terbanyak pada perlakuan padat penebaran 15, 20 dan 25 ekor/5 liter air, hal ini karena pada padat penebaran yang tinggi persaingan sangat besar baik dalam hal makanan, ruang gerak maupun oksigen, sehingga ada beberapa ekor ikan yang mati karena tidak bisa beradaptasi. Selain itu pada wadah yang lebih banyak jumlah ikannya airnya lebih kotor dibandingkan dengan yang jumlah ikannya sedikit. Hal ini disebabkan terjadi penumpukan sisa-sisa makanan dan kotoran ikan dalam perairan yang menghasilkan amoniak. Apabila kadar amoniak ini meningkat melebihi ambang batas normal dalam perairan menyebabkan pertumbuhan ikan menjadi lambat dan bahkan bisa mengalami kematian. Cahyono (2000) menyatakan penumpukan sisa-sisa makanan dan kotoran ikan didalam perairan akan 
menghasilkan amoniak dan jika kadar amoniak tinggi dalam suatu perairan dapat mengakibatkan pertumbuhan ikan menjadi lambat.

\section{Kualitas air}

Kualitas air merupakan faktor penentu sebagai pendukung kehidupan organisme uji. Perameter kualitas air diukur pada minggu awal penebaran, pertengahan dan akhir penelitian. Parameter yang diamati selama penelitian meliputi: Suhu, pH, dan DO. Data hasil pengukuran parameter kualitas air masingmasing perlakuan terdapat pada Tabel 5:

Tabel 5. Data Kisaran Kualiatas Air

\begin{tabular}{|c|c|c|c|c|c|}
\hline $\begin{array}{l}\text { Parameter } \\
\text { kualitas air }\end{array}$ & $\begin{array}{l}\text { Perlakuan } \\
\text { A ( } 5 \text { ekor })\end{array}$ & $\begin{array}{l}\text { Perlakuan } \\
\text { B (10 ekor) }\end{array}$ & $\begin{array}{l}\text { Perlakuan C } \\
\text { (15 ekor) }\end{array}$ & $\begin{array}{l}\text { Perlakuan D } \\
\text { (20 ekor) }\end{array}$ & $\begin{array}{l}\text { Perlakuan E } \\
\text { ( } 25 \text { ekor) }\end{array}$ \\
\hline Suhu $\left({ }^{\circ} \mathrm{C}\right)$ & $25-26$ & $25-26$ & $25-26$ & $25-26$ & $25-26$ \\
\hline $\mathrm{pH}$ & 7.00-7.94 & 7.00-7.94 & 7.00-7.94 & 7.00-7.94 & 7.00-7.94 \\
\hline DO & 5.7 & 5.7 & 5.7 & 5.7 & 5.7 \\
\hline
\end{tabular}

Hasil pengukuran suhu selama penelitian berkisar antara $25^{\circ} \mathrm{C}-27^{\circ} \mathrm{C}$. Suhu dalam wadah pemeliharaan masih dalam kisaran yang layak bagi pertumbuhan dan kelengsungan hidup ikan nila selama penelitian. Hal tersebut sesuai pendapat Widiyati, A (1991) bahwa suhu yang optimum bagi pertumbuhan ikan nila berkisarantara $25^{\circ} \mathrm{C}-30^{\circ} \mathrm{C}$, suhu air mempengaruhi pertumbuhan ikan karena akan mempengaruhi nafsu makan pada ikan.

Nilai keasaman air $(\mathrm{pH})$ masih dalam kisaran yang optimum untuk kehidupan benih ikan nila yaitu 7.0-7.4 sehingga toleransi pada $\mathrm{pH}$ air selama penelitian masih dalam kisaran yang layak untuk pemeliharaan ikan nila. Menurut Widiyati (1991) mengatakan bahwa kisaran $\mathrm{pH}$ air yang optimal untuk pemeliharaan ikan nila yaitu 7-8, di tambahkan Sumpeno (2005) bahwa tinggi rendahnya $\mathrm{pH}$ dalam suatu perairan dipengaruhi oleh jumlah kotoran dalam lingkungan perairan, khususnya sisa pakan dan hasil metabolism.

Sedangkan hasil pengukuran DO selama penelitian masih dalam kisaran yang optimum untuk kehidupan benih ikan nila rata-rata yaitu $5.7 \mathrm{ppm}$. Hal tersebut sesuai pendapat Rukmana (2004), ikan nila termasuk ikan yang tahan dalam kondisi kekurangan oksigen. Jika terjadi kekurangan oksigen, ikan nila langsung mengambil oksigen dari udara bebas, ikan nila bisa bertahan hidup lama di darat tanpa air.Kandungan oksigen yang baik untuk ikan nila berkisar antara 3-5 ppm. 


\section{KESIMPULAN}

Hasil penelitian tentang kepadatan yang berbeda terhadap pertumbuhan dan sintasan benih ikan nila $O$. niloticus dalam wadah terkontrol dapat disimpulkan bahwa:

1. Kelima perlakuan terhadap pertumbuhan spesifik harian benih ikan Nila gift $O$. niloticus menunjukkan hasil tidak berbeda nyata.

2. Sintasan tertinggi diberikan pada perlakuan B sebesar $60 \%$, sedangkan sintasan terendah pada perlakuan E sebesar $8(\%)$.

3. Hasil pengukuran kualitas air selama penelitian masih layak untuk kehidupan benih ikan nila, dimana suhu 25-26, pH 7.00 - 7.94 dan DO 5.7.

\section{DAFTAR PUSTAKA}

Cahyono. 2000. Budidaya Ikan Air Tawar. Kanisius. Jakarta.

Gaspersz V. 1991. Metode Perancangan Percobaan. Armico. Bandung.

Hatimah. 1991. Pengaruh Padat Penebaran Terhadap Pertumbuhan Ikan (Di Kolam. Bulletin Penelitian Perikanan Darat 10 (1): 64-69

Khairuman dan Amri K. 2008. Budidaya Ikan Konsumsi. PT Agromedia pustaka. Jakarta

Kadarini T, Lili S, Marendra G. 2010. Pengaruh Padat Penebaran Terhadap Sintasan dan Pertumbuhan Benih Ikan Hias Silver Dollar (Metynnis hypsauhen) dalam Sistem Resirkulasi. Prosiding Forum Inovasi teknologi Akuakultur.

Rukmana R. 2004. Ikan Nila Budidaya dan Prospek Agribisnis. Kanisius, Yogyakarta.

Sumpeno. 2004. Pertumbuhan dan kelangsungan hidup benih ikan lele dumbo (clarias sp) pada padat penebaran 15, 20, 25 dan 30 ekor/liter dalam pendederan secara indoor dengan sistem resirkulasi. Skripsi. Budidaya perairan fakultas perikanan dan ilmu kelautan. IPB. Bogor. $35 \mathrm{hlm}$.

Widiyati A. 1991. Petunjuk Teknis Budidaya ikan nila. Puslitbang perikanan, Badan Litbang Pertanian. 